\title{
Sustainable potato production: A Model of Potato Production at Low Latitude Plateau in winter, Yunnan Province, China
}

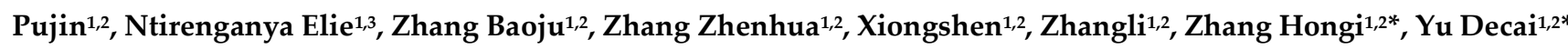 \\ 1. Plant Protection College, Yunnan Agricultural University, Kunming, 650201, China; \\ 2. Key Laboratory of Agrobiodiversity and Pest Control,of Yunnan Province, Kunming 650201, China; \\ ntirenganya_elie@stu.ynau.edu.cn \\ ${ }^{3}$ State Key Laboratory of Conservation and Utilization of Biological Resources of Yunnan Province, Kunming \\ 650201, China); 2018230011@ stu.ynau.edu.cn \\ * Correspondence: 459025316@qq.com; Tel.: (86) 13388859299; https://orcid.org/0000-0001-5227-9101; Y.D.C, \\ zhqnghongij111@163.com;Tel.: (86) 18088121347; Z.H.J.
}

\begin{abstract}
Potato (Solanumtuberosum L.) is the world's largest non-cereal crop, occupying a position critical for global food security, the fourth largest crop food in China. Due to its location and weather conditions, Yunnan province is thefourth largest potato producer in China with twice yearly production system. However, compared to high number of consumers, potato yield is still low to satisfy the population need. In this study, we have analyzed impacts of three cultivation factors: (1) three cultivation models (T1, T2, and T3), (2) planting density (T1, T2, and T3), (3) soil covering (T1, T2, T3, T4) on plant growth, and yield production. The soil moisture content, temperature, roots growth, stems development, leaf area index, and number-weight of tubers per plant and per plot (g) have significantly increased with commercial yield average of 3tones/mu. This suggests that the combination of these three factors would be a great potato extension model in winter climate zones similar to Yunnan Province. This will contributes in satisfaction of the world population potato consumption need.
\end{abstract}

Keywords: potato cropping systems; cultivation model; planting density; soil cover; sustainable productivity

\section{Introduction}

Due to the world population exponential growth about 8 billion (https://population.un.org/wpp/) of today, to the life standards improvement conditions which led to the increase of migrant to urban zones, there is a growing concern associated with ecological alteration and climate change. This extreme population growth and migration have led to 21st century pressure on food production system to satisfy the growing population with a smaller rural labor force [7]. This led to all actors to invest in sustainable crop intensification to improve the production system of particular crops. Potato is the third most important food crop in the world after rice and wheat in terms of human consumption. More than a billion people worldwide depend on potato with global annual total crop production exceeds 300 million metric tons [1] at the Average of consumption per capita $32.3 \mathrm{~kg}$ in 2018 according to Faostat. Since 1960s, potato production area has exponentially increased over all other food crops in developing countries. It is an initial element in the food system for millions of people across Asia, South America, and Africa [2].

Since 1993, China is the world top potato producing country at the total production area of potato 4.9 million ha in 2017, which was 6 th crop after maize ( 42.4 million ha), rice (30.7 million ha), wheat (24.5 million ha), soybean and rapeseed (NBSC, http://www.stats.gov.cn/tjsj/). China's top priority in national economic and social development strategy is sustainable agriculture to feed about 1.4 billion of people in its mainland. Potato production has double in recent 10 years and with expectation of progressive increase due China Government effort in strengthening the food production system. Efforts have been made in researches and sustainable crop extension approach in 
partnership with international governmental and research institutions [6] to improve potato quality and quantity production. China's updated annual potato production data shows about 100 million metric tons representing $33.4 \%$ of the world total production at yield average of $17.045 \mathrm{Kg} / \mathrm{Ha}$ [3]. Yunnan province is located in southwest of China, potato production and cultivated area ranked as fourth in the country and representing $10.12 \%$ of China's total potato-planting area after Sichuan $(14.16 \%)$, Guizhou (12.64\%), Gansu (12.25\%) [4]. This province is $383,390 \mathrm{~km} 2$ of which $84 \%$ is hills and mountains, $10 \%$ undulating, $6 \%$ flat and valley landscape [5] which is a restraint to potato production system. However, due to the geographical location, the average annual rainfall is ranging from $500-2900 \mathrm{~mm}$, altitude of $600-1600 \mathrm{~m}$, with winter average temperature of $10-21^{\circ} \mathrm{C}$ and a combination of drought and medium rain, sufficient sunlight, heat, and big difference of day and night temperature provide a better natural environment for the growth of potatoes two times yearly [8]. Potato yield is expected to exponentially increase as potato seed quality improves, cultivation technologies advancement, adoption of new cultivars, and extension of potato farming land due to increase of consumers. In mountainous landscape like Yunnan, ridges and furrows at sloping fields are both important in rainwater collection and potato yield increase with consideration of soil-water conservation in farming fields. The current common methods of potato planting in plateau landscape are both flat field cultivation and single ridge-single row methods with yield range from 0.8-1.5tones/mu [9-10]. The effects of cultivation model, planting density, and soil cover on soil moisture content, temperature, crop growth, and yields were studied over a period of 10 years in Yunnan Province. To identify a high-efficiency potato cultivation model, we have compared different parameters; the best performance method could be identified and suggested in potato extension and production system in different parts of the World of similar conditions to Yunnan Province.

\section{Materials and Methods}

\subsection{Basic experimental design}

Xuanshu 2 Potato variety, provided by Yunnan Agricultural University was used in this study. Seeds were collected from Qujing Prefecture, Xuan Wei Agriculture Academy of Science.

For potato planting, slightly acidic (PH5.3-PH7) plots were selected, ploughed about $35 \mathrm{~cm}$ deep, and turned to reach the sowing state. Generally, each potato seed has checked for bud eyes and sliced into pieces of 45-70g weight according to the seed size (Fig. 1). The slicer was sterilized and the disinfected by $0.4 \%$ potassium permanganate solution and $75 \%$ alcohol. Each sowed potato piece was required to have at least 1 bud eye, preferably 2 to 3 bud eyes. The sowing depth was generally $8-10 \mathrm{~cm}$ (from the upper part of the tuber to the upper part of the ridge platform). NPK: 2:1:4 fertilizer in combination with soil preparation was applied per sowing at the rate of $\mathrm{N}: 50-130 \mathrm{~kg} / \mathrm{ha} ; \mathrm{P} 2 \mathrm{O} 5$ : 170-200kg/ha; K2O: $200-300 \mathrm{~kg} / \mathrm{ha}$ in the whole growth period.

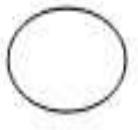

A

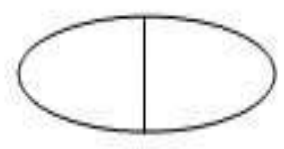

B
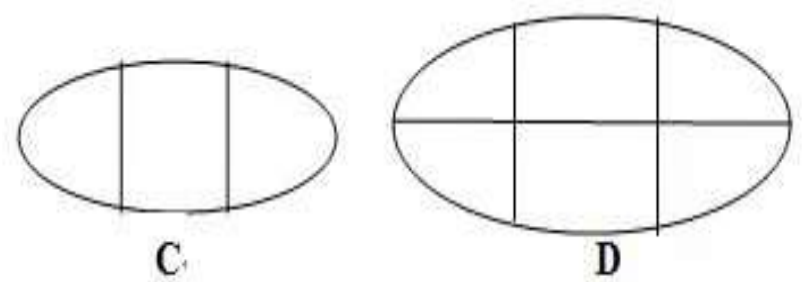

Figure 1. Potato seed weight and seed preparation.(A) $45-60 \mathrm{~g}$, seed was cultivated as whole potato; (B) $90-120 \mathrm{~g}$, seed is cut into two equal pieces; (C) 180-270g, seed was cut into three pieces; (D) 240-420g, seed was cut into six pieces. 


\subsubsection{Planting density experimental design}

The experiment was carried out in Shiping County, Honghe Prefecture, Yunnan Province $\left(23^{\circ} 40^{\prime} \mathrm{N} 102^{\circ} 30^{\prime} \mathrm{E}\right)$. Experimental cultivation mode was set up with three density treatments $\mathrm{T} 1, \mathrm{~T} 2, \mathrm{~T} 3$, the row spacing was $80 \mathrm{~cm}$ whereas plant spacing of trials were $\mathrm{T} 1: 15 \mathrm{~cm}, \mathrm{~T} 2: 18 \mathrm{~cm}, \mathrm{~T} 3: 21 \mathrm{~cm}$, the number of plants per ha mu was 5558, 4631 and 3970 respectively (Tab. 1).

Table 1. Treatment with different planting densities.

\begin{tabular}{ccc}
\hline Treatment & Plant spacing & Plants per acre \\
\hline T1 & $15 \mathrm{~m}$ & 5558 \\
T2 & $18 \mathrm{~cm}$ & 4631 \\
T3 & $21 \mathrm{~cm}$ & 3970 \\
\hline
\end{tabular}

\subsubsection{Experimental design of soil covering method}

Soil covering experiment was conducted in two trials (Open field experiment and green house potted experiment); both have tested in fourtreatments (T1, T2, T3, T4) whereT1 was covered once, T2 was covered twice, T3 was covered three times, and T4 was the control without soil covering.The open field experiment was conducted at $300 \mathrm{~m}^{2}$ plot with purpose to measure the post-harvest yield per $60 \mathrm{~m}^{2}$, whereas repeated four times treatments of four potted seedlings were conducted in greenhouse to test the plant growth with special focus on roots and stem development. The growth of the roots of the potato plants were measured after 100 days of cultivation.After the potatoes were cultured under greenhouse conditions for 100 days, the roots and stems development were investigated. Covering time: When the seedling emergence rate reached $40-50 \%$, the first soil cover trials were conducted at $5 \mathrm{~cm}, 10 \mathrm{~cm}$ and $15 \mathrm{~cm}$ of height, and fourth trial was used as control. During the harvesting period, the yield was investigated and measured per plot size in open field experiment.

\subsubsection{Experimental design of planting methods}

The experiment was conducted in 3 prefectures of Yunnan Province: Maomuzui Village, Shiping County, Honghe Prefecture, $\left(23^{\circ} 40^{\prime} \mathrm{N} 102^{\circ} 30^{\prime} \mathrm{E}\right)$. The basic test treatments methods adopt cultivation modes of 3 trial plots (Tab. 2): (1) Flat field or traditional cultivation (T1) (Fig. 2a) 1: 1.50 meters with $30 \times 40 \mathrm{~cm}$ row spacing, 5 plants per row, at the rate of 4631 plants/mu; (2) Single ridge-single row cultivation (T2) (Fig. 2b): the plant spacing is $80 \times 15 \mathrm{~cm}, 5558$ plants/mu; (3) Single-ridge-double row cultivation (T3) (Fig. 2c): the plant-row spacing is $120 \times 20 \mathrm{~cm}, 5558$ plants $/ \mathrm{mu}$. The area of each plot was $150 \mathrm{~m} 2$ and 9 plots in total were arranged in random blocks (Tab. 2).

Table 2. the treatment plot of potato in different planting density.

\begin{tabular}{ccc}
\hline Cultivation mode & row spacing & Plants per mu \\
& & $30 \times 40 \mathrm{~cm}$ \\
T1 & $80 \times 15 \mathrm{~cm}$ & 5631 \\
T2 & $120 \times 20 \mathrm{~cm}$ & 558 \\
T3 & 558 & \\
\hline
\end{tabular}



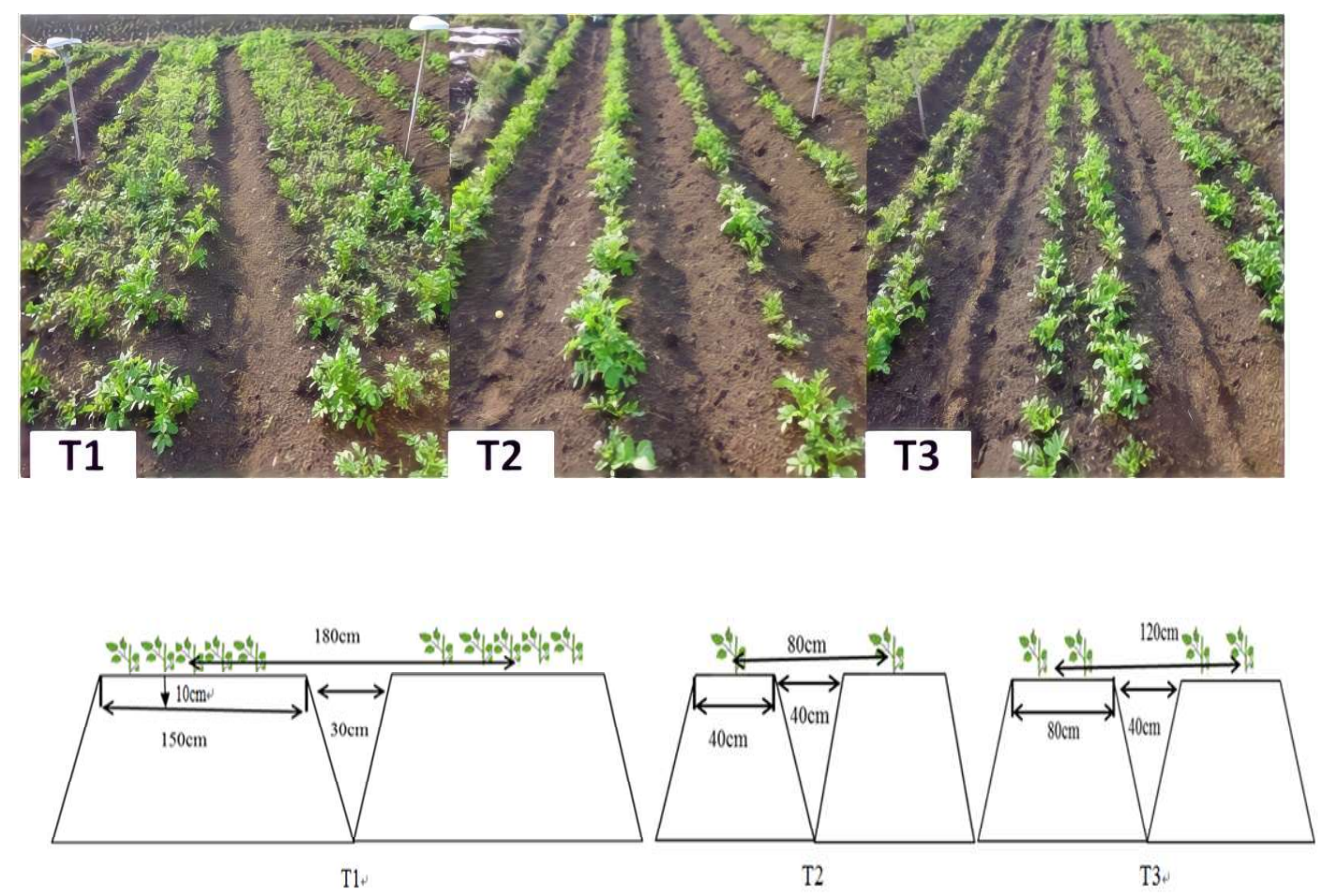

Figure 2. Potato seedlings cultivation models.(a) Traditional cultivation T1; (b) Single ridge-single row T2; (c) Single ridge-double row $\mathrm{T} 3$.

Note: Remember that 1 ton equals $1000 \mathrm{~kg}$ and 1 hectare equals $15 \mathrm{mu}=10.000 \mathrm{~m} 2$.

\subsection{Surveyed Indicators}

a. Investigation of potato seedling rate:After the second soil covering, all potato seedlings in 9 plots were investigated, the number of seedlings emerged in each plot was recorded and the seedling growth rate was calculated.

b. Investigation of potato agronomic characters:Five-point sampling method was used to record various agronomic characters of the potato plants at the flowering stage, two plants from each point were randomly selected, and the number of main stems, branches, and the leaf size index , underground stem length, plant height, stem thickness, root-shoot ratio and root level were recorded. The number of side emerged branches and leaf buds grown up to $10 \mathrm{~cm}$ or more were considered.

The size of randomly selected leaves were measured the following formula

Leaf area $(\mathrm{cm} 2)=$ Dry weight of all leaves to be measured $(\mathrm{W}) \times$ sample leaf area (a)

Dry weight was obtained after exposing fresh leaves at $105^{\circ} \mathrm{C}$ for 30 minutes to remove water content and dried at $80^{\circ} \mathrm{C}$ in 48 hours for constant weight. Plant height was measured from soil level to the aerial highest growing point; Stem thickness was measured using the first and second branches from the ground whereas Root to shoot ratio: the ratio of the fresh weight or dry weight of the underground part to the aerial part size were reflecting the correlation between the underground and the aerial part of the plant.

c. Soil temperature and humidity survey: The soil temperature and humidity of all plots were monitored. Monitoring time was during the flowering period (March 10) and the rapid expansion period of potato (March 26). The HOBO MX2304 weatherproof data logger was used as temperature and relative humidity sensor for 24 hours monitoring.

\subsection{Potato production recording}


Yield per plant: During the harvesting period, the five-point survey method was adopted in each plot, 2 plants were randomly selected from every point to record the weight per plant. The number of knotted and commercial potatoes was weighted. Normal potato pieces with a weight of more than $250 \mathrm{~g}$, no mechanical damage, no deformity, and no disease were considered commercial; deformed, greener, diseased and pieces weighting less than $250 \mathrm{~g}$ were considered non-commercial.

Yield per plot: Three points were randomly selected in each plot, every point was $3 \mathrm{~m}$ larger, commercial and non-commercial potatoes were weighted.

Statistical analysis: The experimental data were analyzed with SPSS18.0.

\section{Results}

3.1. Effect of planting density on plant growth and yield

\subsubsection{Planting density Effect on yield per plant}

The yield by a single plant after harvesting period shows that there was a significant difference in the specific potato planting densities. Proportion was calculated by the weight of commercial potatoes to the weight of a single potato plant harvest. T3 commercial potato plant accounts the lower proportion of weight and showed a higher number of potato pieces of different sizes whereas T1 has showed a higher proportion of high weighed pieces (Tab. 3).

Table 3. Potato yield in the harvest per plant.

\begin{tabular}{cccccc}
\hline Treatment & Tubers weight per plant & Tubers & Commodity potato weight & Commodity potato & Proportion \\
\hline T1 & $0.91 \pm 0.26$ & $4.33 \pm 1.15$ & $0.90 \pm 0.27$ & $3.67 \pm 0.58$ & $0.98 \pm 0.03 \mathrm{a}$ \\
T2 & $0.92 \pm 0.30$ & $4.33 \pm 0.58$ & $0.86 \pm 0.33$ & $3.00 \pm 0.00$ & $0.92 \pm 0.06 \mathrm{ab}$ \\
T3 & $0.99 \pm 0.39$ & $5.00 \pm 1.73$ & $0.81 \pm 0.36$ & $3.00 \pm 1.73$ & $0.81 \pm 0.08 \mathrm{~b}$ \\
\hline
\end{tabular}

\subsubsection{Planting density Effect on yield per plot $(60 \mathrm{~m} 2)$}

The results of the yield per plot showed that the weight of commercial potatoes, the weight of non-commercial potatoes, the weight of green-headed potatoes, the yield per plot and the commodity rate of the total yield between different processing areas were not significantly different. However, from the point of view of the equivalent per mu, the yield of T1 at high-density planting is higher than that of two other treatments (T2 \& T3) nearly $500 \mathrm{~kg}$, which has a greater impact on the total yield production (Tab. 4).

Table 4. Yield in the harvest yield per plot (60m2).

\begin{tabular}{ccccccc}
\hline \multirow{2}{*}{ Treatment } & $\begin{array}{c}\text { Commodity } \\
\text { potato weight }\end{array}$ & $\begin{array}{c}\text { Non-commercial potato Weight of green } \\
\text { weight }\end{array}$ & potato & plot yield & \multirow{2}{*}{ Commodity rate } & Yield per mu \\
\hline T1 & $200.73 \pm 23.56$ & $71.77 \pm 25.05$ & $1.23 \pm 0.32$ & $273.73 \pm 47.3$ & $0.74 \pm 0.04$ & $2852.8 \pm 493$ \\
T2 & $164.03 \pm 19.48$ & $54.47 \pm 7.26$ & $1.13 \pm 0.35$ & $219.63 \pm 14.3$ & $0.75 \pm 0.04$ & $2288.99 \pm 155$ \\
T3 & $170.73 \pm 2.54$ & $55.30 \pm 18.91$ & $1.50 \pm 0.8$ & $227.53 \pm 16.5$ & $0.75 \pm 0.07$ & $2371.32 \pm 172$ \\
\hline
\end{tabular}

\subsection{Effects of different soil covering methods on potato}

\subsubsection{Effects of different soil covering methods on potato roots}

Through potted experiments, it was found that different soil covering depths had a greater impact on the growth of potato roots, and the root system-level increased with soil covering compared to plants that were not covered. The potted experiments found that the root freshness in repeated soil cover was higher than that of the uncovered soil treatment, and the root freshness weight of the three-time covered soil was significantly higher than that of the control and other treatments (Fig. 3). 


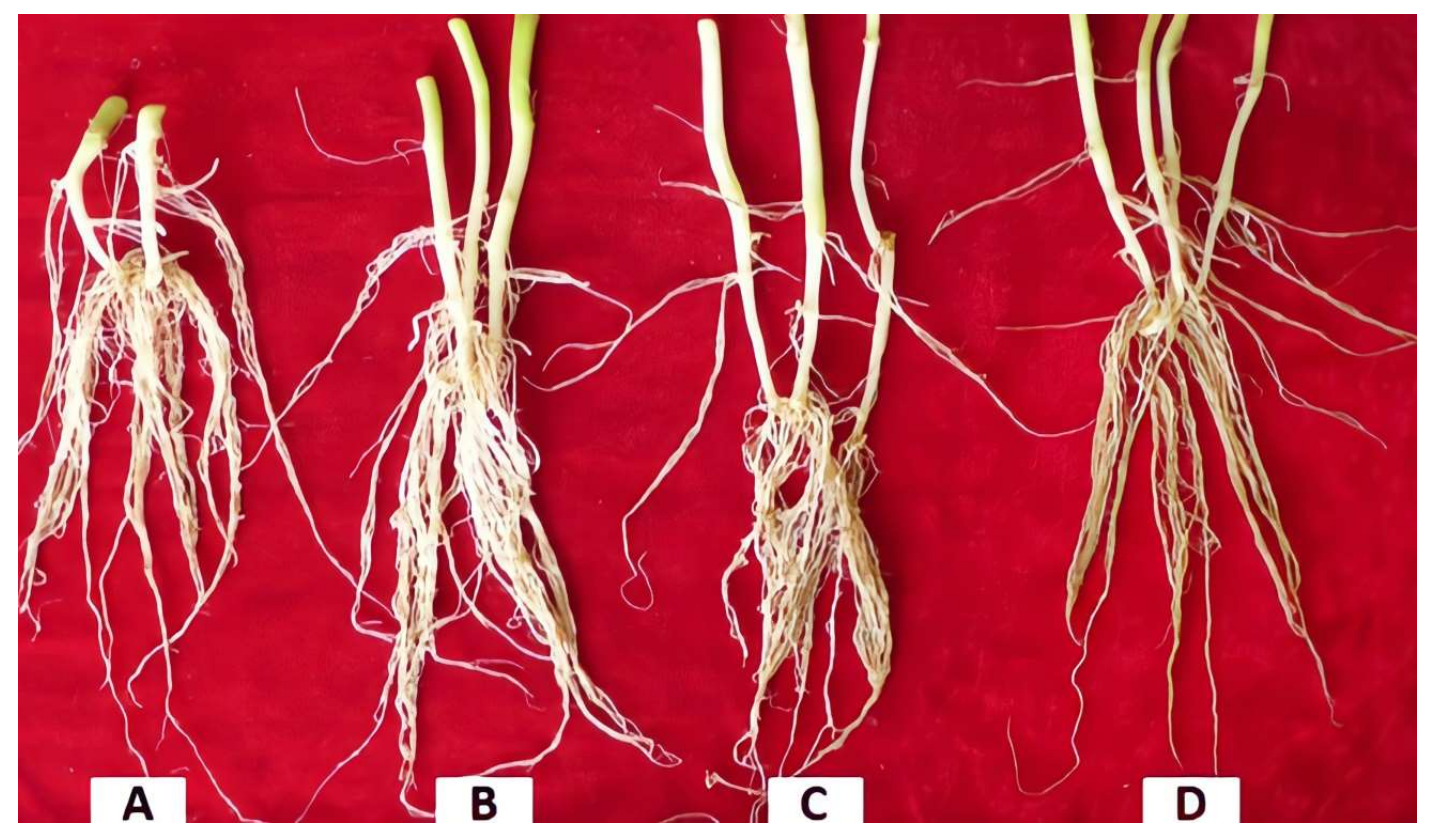

Figure 3. Stems and Roots growth at different soil covering in potted experiment. (A) control without soil cover; (B) Single soil cover; (C) Twice soil cover; (D) Three soil cover.

At the same time, the length of underground stems was also greatly affected by the soil cover. The length of underground stems without cover treatment was only $9.2 \mathrm{~cm}$, which is significantly lower than that of covered treatments (T2=18.6 > T3=17.2 > $\mathrm{T} 1=15.5 \mathrm{~cm})$. The two times soil cover treatment (T2) was significantly higher than the one cover, but the difference between the three treatments (T1, T2, \& T3) was not significant (Tab. 5).

Table 5. Plant root growth of different covering soil.

\begin{tabular}{llccccccc}
\hline Treatment & tuber number & $\begin{array}{c}\text { Potato weight } \\
(\mathbf{g})\end{array}$ & SLFW $(\mathbf{g})$ & SLDW $(\mathbf{g})$ & $\begin{array}{c}\text { Root fresh } \\
\text { weight }(\mathbf{g})\end{array}$ & $\begin{array}{c}\text { Root dry } \\
\text { weight }\end{array}(\mathbf{g})$ & Root level & $\begin{array}{c}\text { Root length } \\
\text { (cm) }\end{array}$ \\
\hline $\mathrm{T} 1$ & $6.0 \pm 3.0$ & $50.4 \pm 10.1$ & $78.8 \pm 8.2$ & $5.5 \pm 0.8$ & $8.7 \pm 5.1 \mathrm{~b}$ & $0.96 \pm 0.14$ & $6.3 \pm 0.6$ & $15.5 \pm 2.2 \mathrm{~b}$ \\
$\mathrm{~T} 2$ & $6.0 \pm 2.7$ & $58.8 \pm 20.9$ & $67.3 \pm 36.6$ & $6.2 \pm 1.4$ & $8.7 \pm 1.1 \mathrm{~b}$ & $1.07 \pm 0.12$ & $6.3 \pm 1.2$ & $18.6 \pm 1.6 \mathrm{a}$ \\
$\mathrm{T} 3$ & $4.7 \pm 0.6$ & $53.6 \pm 2.6$ & $86.7 \pm 11.6$ & $6.6 \pm 1.2$ & $16.3 \pm 2.6 \mathrm{a}$ & $1.25 \pm 0.44$ & $6.3 \pm 1.2$ & $17.2 \pm 1.2 \mathrm{ab}$ \\
$\mathrm{CK}$ & $3.7 \pm 2.52$ & $33.2 \pm 20.7$ & $52.0 \pm 17.8$ & $4.4 \pm 0.7$ & $6.0 \pm 3.1 \mathrm{~b}$ & $0.69 \pm 0.14$ & $5.0 \pm 1.0$ & $9.2 \pm 1.6 \quad \mathrm{c}$ \\
\hline
\end{tabular}

Where SLFW is stem and leaf fresh weight; SLDW is stem and leaf dry weight.

\subsubsection{Effects of different soil covering methods on yield in open field experiments}

Field experiments results found that different soil covering methods had no significant effect on potato yield, but significantly affected the commercial nature of the plants productivity. The green head rate of potato treated with uncovered soil was significantly higher than that of covered soil. The difference between the other three soil covering treatments (T1, T2, and T3) was not significant, and the number of green heads potatoes was reduced in two times soil covering treatment (Tab. 6).

Table 6. Investigation of yield harvest in different covering soil treatments.

\begin{tabular}{|c|c|c|c|c|c|c|}
\hline Treatment & $\begin{array}{c}\text { Commodity potato } \\
\text { weight }\end{array}$ & $\begin{array}{c}\text { Non-commercial potato } \\
\text { weight }\end{array}$ & $\begin{array}{c}\text { Weight of green } \\
\text { potato }\end{array}$ & plot yield & Commodity potato & Yield per mu \\
\hline $\mathrm{T} 1$ & $149.13 \pm 14$ & $50.50 \pm 18.27$ & $1.37 \pm 0.75 \mathrm{~b}$ & $201 \pm 5$ & $74.5 \pm 8.8$ & $2328 \pm 55$ \\
\hline $\mathrm{T} 2$ & $151.10 \pm 13.02$ & $42.07 \pm 7.31$ & $0.50 \pm 0.29 b$ & $194 \pm 15$ & 78.13 .6 & $2243 \pm 169$ \\
\hline $\mathrm{T} 3$ & $151.53 \pm 9.49$ & $41.83 \pm 9.81$ & $2.13 \pm 0.98 b$ & $196 \pm 12$ & $77.7 \pm 4.5$ & $2264 \pm 135$ \\
\hline CK & $149.73 \pm 25.69$ & $46.63 \pm 17.10$ & $9.17 \pm 3.14 \mathrm{a}$ & $206 \pm 33$ & $72.9 \pm 5.3$ & $2380 . \pm 385$ \\
\hline
\end{tabular}


The research investigated the growth of plants in three planting methods in Shiping County. The seedling stage survey and analysis found that the difference in seedling rates between the three treatments was not significant (Tab. 7). The various growth traits of potatoes were investigated during the budding period. From the data analysis in (Tab. 5), it can be seen that the root level, underground stem length and leaf area of the plants differed significantly from different planting methods. The treatment of T2 at the root level was significantly higher than that of T1 and T3. The difference between T3 and T1 was not significant, but numerically, the root level of T3 was higher than that of T1 (Tab. 7). There is a significant difference in the length of underground stems between the three planting methods. The length of underground stems of T2 was $15.00 \mathrm{~cm}$, which is significantly higher than that of $\mathrm{T} 1$ and $\mathrm{T} 3(\mathrm{~T} 2=15.00>\mathrm{T} 3=11.83>\mathrm{T} 1=8.92 \mathrm{~cm})$.

For the leaf area index, the analysis of the results shows that the leaf area index of a T3 is 199.7, which is significantly higher than that of T2 (156.67) and T1 (153.58) respectively. This predicts that the T3 planting density would be suitable to maximize the photosynthetic capacity of the plant which is proportionally linked to the stem and underground roots development (Tab. 7). However, other indicators of plants involved in the three cultivation methods, such as seedling developmental rate, number of main stems, number of branches, plant height and stem thickness, didn't present a significant difference (Tab. 7). 
Table 7. ANOVA of potato growth in different cultivation models.

\begin{tabular}{|c|c|c|c|c|c|c|c|}
\hline Growth index & Treatment & $\mathbf{N}$ & Average & standard deviation & $\begin{array}{c}\text { significance of } \\
\text { difference }\end{array}$ & $\mathbf{F}$ & $\mathbf{P}$ \\
\hline \multirow{3}{*}{ Seedling emergence } & $\mathrm{T} 1$ & 5 & 0.89 & 0.03 & $\mathrm{~A}$ & \multirow{4}{*}{0.339} & \multirow{4}{*}{0.719} \\
\hline & $\mathrm{T} 2$ & 5 & 0.89 & 0.03 & $\mathrm{~A}$ & & \\
\hline & $\mathrm{T} 3$ & 5 & 0.90 & 0.03 & A & & \\
\hline & $\mathrm{T} 1$ & 6 & 1.17 & 0.41 & A & & \\
\hline \multirow[t]{2}{*}{ Main stem number } & $\mathrm{T} 2$ & 6 & 1.33 & 0.52 & $\mathrm{~A}$ & \multirow[t]{3}{*}{1.154} & \multirow[t]{3}{*}{0.342} \\
\hline & $\mathrm{T} 3$ & 6 & 1.00 & 0.00 & A & & \\
\hline \multirow{3}{*}{ Branch number } & $\mathrm{T} 1$ & 6 & 2.17 & 1.83 & A & & \\
\hline & $\mathrm{T} 2$ & 6 & 3.00 & 1.26 & A & \multirow[t]{3}{*}{0.394} & \multirow[t]{2}{*}{0.681} \\
\hline & $\mathrm{T} 3$ & 6 & 3.00 & 2.37 & $\mathrm{~A}$ & & \\
\hline \multirow{3}{*}{ Root layer } & $\mathrm{T} 1$ & 6 & 2.67 & 0.82 & $\mathrm{~B}$ & & \\
\hline & $\mathrm{T} 2$ & 6 & 5.50 & 1.05 & A & \multirow[t]{3}{*}{19.923} & \multirow[t]{2}{*}{0.000} \\
\hline & $\mathrm{T} 3$ & 6 & 3.00 & 0.63 & $\mathrm{~B}$ & & \\
\hline \multirow{3}{*}{ Roots length } & $\mathrm{T} 1$ & 6 & 8.92 & 1.74 & $\mathrm{C}$ & & \multirow{4}{*}{0.000} \\
\hline & $\mathrm{T} 2$ & 6 & 15.00 & 1.55 & A & \multirow[t]{3}{*}{21.900} & \\
\hline & $\mathrm{T} 3$ & 6 & 11.83 & 1.47 & $\mathrm{~B}$ & & \\
\hline \multirow{3}{*}{ Leaf area } & $\mathrm{T} 1$ & 6 & 153.58 & 32.66 & $\mathrm{~B}$ & & \\
\hline & $\mathrm{T} 2$ & 6 & 156.67 & 18.94 & $\mathrm{~B}$ & \multirow[t]{2}{*}{3.697} & \multirow[t]{2}{*}{0.050} \\
\hline & $\mathrm{T} 3$ & 6 & 199.73 & 42.61 & A & & \\
\hline & $\mathrm{T} 1$ & 6 & 26.33 & 7.45 & A & & \\
\hline Plant height & $\mathrm{T} 2$ & 6 & 31.83 & 7.03 & A & 1.040 & 0.378 \\
\hline & $\mathrm{T} 3$ & 6 & 28.00 & 5.73 & A & & \\
\hline & $\mathrm{T} 1$ & 6 & 14.06 & 1.81 & A & & \\
\hline Stem diameter & $\mathrm{T} 2$ & 6 & 13.19 & 1.56 & A & 0.501 & 0.616 \\
\hline & $\mathrm{T} 3$ & 6 & 13.45 & 1.22 & A & & \\
\hline & $\mathrm{T} 1$ & 6 & 149.14 & 38.80 & A & & \\
\hline Ground fresh weight & $\mathrm{T} 2$ & 6 & 169.18 & 35.69 & A & 0.273 & 0.765 \\
\hline & $\mathrm{T} 3$ & 6 & 158.47 & 62.05 & A & & \\
\hline & $\mathrm{T} 1$ & 6 & 4.17 & 2.71 & A & & \\
\hline Tuber number & $\mathrm{T} 2$ & 6 & 3.83 & 1.17 & A & 0.462 & 0.639 \\
\hline & $\mathrm{T} 3$ & 6 & 3.17 & 1.17 & A & & \\
\hline & $\mathrm{T} 1$ & 6 & 36.22 & 16.04 & $\mathrm{~A}$ & & \\
\hline Tuber weight & $\mathrm{T} 2$ & 6 & 44.31 & 22.05 & $\mathrm{~A}$ & 0.476 & 0.630 \\
\hline & $\mathrm{T} 3$ & 6 & 49.93 & 32.44 & A & & \\
\hline & $\mathrm{T} 1$ & 6 & 17.01 & 9.24 & A & 0.029 & 0.971 \\
\hline Underground fresh & $\mathrm{T} 2$ & 6 & 16.15 & 3.16 & $\mathrm{~A}$ & & \\
\hline & $\mathrm{T} 3$ & 6 & 16.51 & 4.42 & $\mathrm{~A}$ & & \\
\hline & $\mathrm{T} 1$ & 6 & 2.82 & 1.70 & $\mathrm{~A}$ & & \\
\hline Underground ary & $\mathrm{T} 2$ & 6 & 2.86 & 2.06 & $\mathrm{~A}$ & 0.469 & 0.634 \\
\hline & T3 & 6 & 2.03 & 1.15 & $\mathrm{~A}$ & & \\
\hline & $\mathrm{T} 1$ & 6 & 6.33 & 1.51 & $\mathrm{~A}$ & & \\
\hline Stolon number & $\mathrm{T} 2$ & 6 & 8.33 & 2.34 & A & 2.067 & 0.161 \\
\hline & $\mathrm{T} 3$ & 6 & 6.67 & 1.51 & A & & \\
\hline & $\mathrm{T} 1$ & 6 & 14.28 & 7.94 & A & & \\
\hline The longest stolon & $\mathrm{T} 2$ & 6 & 7.93 & 2.89 & A & 3.084 & 0.076 \\
\hline & $\mathrm{T} 3$ & 6 & 8.08 & 2.29 & A & & \\
\hline & $\mathrm{T} 1$ & 5 & 4.91 & 1.52 & A & & \\
\hline Stem dry weight & $\mathrm{T} 2$ & 4 & 5.25 & 1.37 & A & 1.079 & 0.380 \\
\hline & $\mathrm{T} 3$ & 3 & 3.71 & 1.30 & A & & \\
\hline & $\mathrm{T} 1$ & 4 & 8.51 & 2.26 & A & & \\
\hline Leaf dry weight & $\mathrm{T} 2$ & 3 & 11.11 & 8.68 & A & 0.518 & 0.614 \\
\hline & T3 & 4 & 7.49 & 2.11 & A & & \\
\hline & $\mathrm{T} 1$ & 4 & 0.51 & 0.22 & A & & \\
\hline $\begin{array}{l}\text { Measurement of leat } \\
\text { dry weight }\end{array}$ & $\mathrm{T} 2$ & 3 & 0.73 & 0.16 & A & 1.541 & 0.272 \\
\hline dry weight & $\mathrm{T} 3$ & 4 & 0.70 & 0.16 & $\mathrm{~A}$ & & \\
\hline
\end{tabular}

3.4. The impact of different planting methods on yield

The experiment measured the yield of three different planting methods. Through the analysis of variance, it can be seen that the constituent factors of the yield of a single plant between different treatments have not significant differences in the weight of potatoes, the number of tubers, the weight of commercial potatoes, and the quantity of commercial potatoes, but from the numerical analysis, it can be seen that the yield of T3 treatment is higher than that of the other two treatments (Tab. 8). Through plot produc- 
tion measurements, it was found that the commodity rate difference between different treatments was not significant, but the green head rate was significantly different. The green head rate of small-scale planting was significantly higher than that of large-scale planting, and the green head rate of a single ridge and a single row was also significantly higher than that of a single ridge and two rows. It can be seen from the analysis of regional production and the actual acre-per-acre production in the region that the difference in output between different treatments is not significant. Comprehensive analysis of the single-ridge and double-row cultivation model has certain application value.

Table 8. Potato yield production from different cultivation models.

\begin{tabular}{|c|c|c|c|c|c|c|c|}
\hline \multirow[b]{2}{*}{$\begin{array}{c}\text { Cultivation } \\
\text { pattern }\end{array}$} & \multicolumn{3}{|c|}{ Yield per plant } & \multicolumn{4}{|c|}{ Yield per plot } \\
\hline & $\begin{array}{l}\text { Potato } \\
\text { weight }\end{array}$ & $\begin{array}{c}\text { Tuber } \\
\text { number }\end{array}$ & $\begin{array}{c}\text { Commercial } \\
\text { potato weight }\end{array}$ & $\begin{array}{c}\text { Commercial } \\
\text { potato number }\end{array}$ & Commodity rate & $\begin{array}{l}\text { Green potato } \\
\text { rate }\end{array}$ & Actual yield/Mu \\
\hline $\mathrm{T} 1$ & $0.8 \pm 0.3$ & $3.8 \pm 1.2$ & $0.65 \pm 0.25$ & $2.5 \pm 1.1$ & $86.4 \pm 1$ & $4.2 \pm 1.2 \mathrm{a}$ & 2983 \\
\hline $\mathrm{T} 2$ & $0.7 \pm 0.1$ & $3.8 \pm 0.8$ & $0.68 \pm 0.13$ & $3.3 \pm 0.5$ & $86.5 \pm 1$ & $2.6 \pm 0.4 \mathrm{~b}$ & 3102 \\
\hline $\mathrm{T} 3$ & $1.1 \pm 0.5$ & $4.7 \pm 1.4$ & $1.00 \pm 0.37$ & $3.5 \pm 0.8$ & $89.8 \pm 3$ & $1.4 \pm 0.2 \mathrm{c}$ & 3108 \\
\hline
\end{tabular}

\subsection{Effects of different planting methods on soil temperature and humidity}

The soil temperature and moisture content of different treatments were recorded during potato plant blooming period to evaluate the impacts of different cultivation models on the soil temperature and humidity.

Temperature: The results showed that the dynamic changes in the soil temperatures of the three treatments were consistent. The temperature has exponentially rise-up from 7 o'clock in the morning to around 15 o'clock in the afternoon, and gradually decreased after reaching the highest value. T2 showed the higher temperature compared to T1 and T3 treatments (T2> T1 > T3) (Fig. 4). There was not significance difference in temperature change between $\mathrm{T} 1$ and $\mathrm{T} 2$ treatments in the morning, but in afternoon, the temperature of T1 rises quickly and decreases slowly. This predicts that T2 treatment may relatively be affected by the environmental conditions rather than T1 which can maintain soil temperature. However, T3 treatment with lowest temperature could have the strong buffering ability to cope with temperature stability.

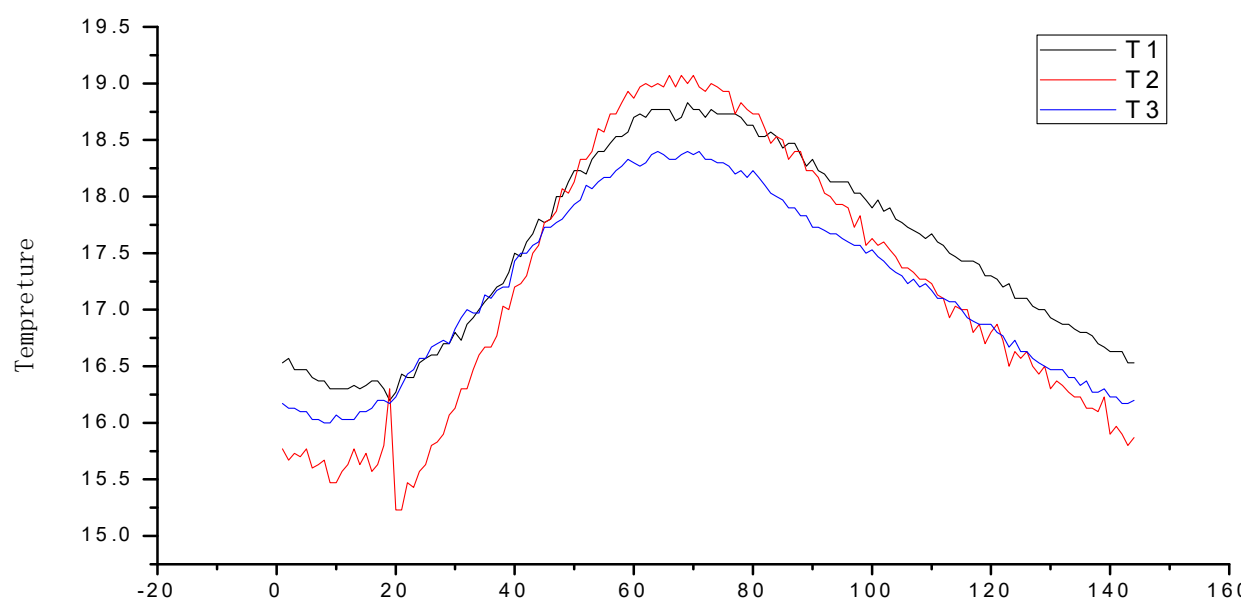

Figure 4. Dynamic change of soil temperature.

Humidity: Potato plantations are quite sensitive to moisture stress, so they need relatively high soil moisture levels to achieve high yields and quality production. The results from 24-hour monitoring of soil moisture content in different treatments shows that, there is no defined variation within three treatments (Fig. 5). The average shows that there is no significant difference in $\mathrm{T} 1$ and $\mathrm{T} 3$ compared to $\mathrm{T} 3$ treatments $(\mathrm{T} 1=57 \%>$ 
$\mathrm{T} 3=53 \%>\mathrm{T} 2=44 \%$ ). In ridges-rows cultivation method, the water loss of $\mathrm{T} 2$ would be faster, and leads to lower moisturizing effect than in T1 and T3 treatments.

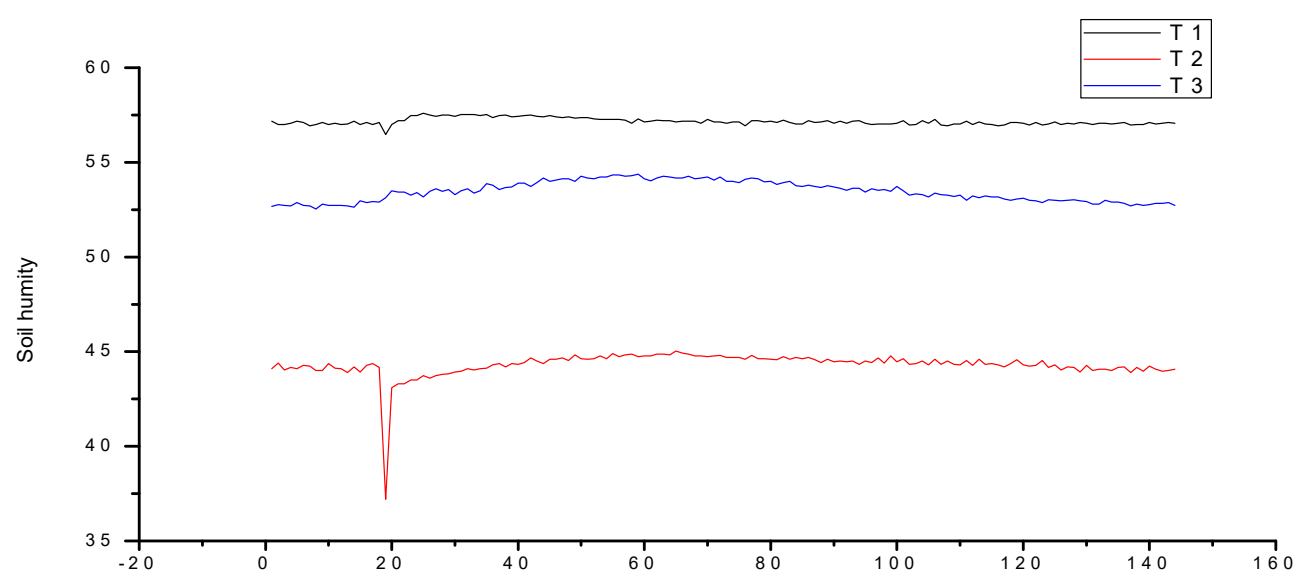

Figure 5. Dynamic change of soil humidity.

From the analysis during the day and at night, it was found that the temperature difference between the three treatments during the day was not different but significantly different at night (T1>T2>T3) (Tab. 9); the change in soil moisture content shows that both T1 and T3 were significantly higher than T2 (Tab. 9).

From the analysis during the day and at night, it was found that the temperature difference between the three treatments during the day was not different but significantly different at night (T1>T2>T3) (Tab. 9); the change in soil moisture content shows that both T1 and T3 were significantly higher than T2 (Tab. 9).

Table 9. The ANOVA of soil temperature and humidity in different cultivation pattern.

\begin{tabular}{cccc}
\hline Time & Treatment & Temperature $\left.{ }^{\circ} \mathbf{C}\right)$ & Humidity $(\%)$ \\
\hline \multirow{2}{*}{ Daily average } & T1 & $17.53 \pm 0.8 \mathrm{a}$ & $57.16 \pm 1.77 \mathrm{a}$ \\
& T2 & $17.20 \pm 1.19 \mathrm{~b}$ & $44.30 \pm 0.69 \mathrm{c}$ \\
& T3 & $17.20 \pm 0.78 \mathrm{~b}$ & $53.46 \pm 0.53 \mathrm{~b}$ \\
Day & T1 & $17.39 \pm 0.96 \mathrm{a}$ & $57.25 \pm 0.20 \mathrm{a}$ \\
& T2 & $17.07 \pm 1.39 \mathrm{a}$ & $44.23 \pm 0.95 \mathrm{~b}$ \\
& T3 & $17.20 \pm 0.89 \mathrm{a}$ & $53.61 \pm 0.59 \mathrm{~b}$ \\
& T1 & $17.67 \pm 0.69 \mathrm{a}$ & $57.07 \pm 0.08 \mathrm{a}$ \\
& T2 & $17.34 \pm 0.95 \mathrm{~b}$ & $44.38 \pm 0.24 \mathrm{c}$ \\
\end{tabular}

\section{Discussion}

Cultivation and planting models: The ridges-double-row cultivation model of has showed the significant different in potato commercial products compared to traditional and ridge-single row cultivation method. In agriculture system, the most important is time saving, resources management and yield projection. Ridges-rows cultivation model has been introduced and showed irrigation facilitation, fertilizers and related resources as well as land management in potato production system [14]. This method can also improve the microclimate of the field to soil moisturizing effect [20] and can increase potato quality and quantity production [9]. In this study, the ridges-double-row cultivation technique has positively impacted the length of underground stems, the root level, leaf area (Tab. 7), and significant commercial yield per mu (Tab. 8). This model could effectively promote the increase of potato production, optimize labor productivity [16], and reduce economic losses and operating costs, by improving the economic benefits of farmers [21]. 
Planting density: In planting and production, reasonable regulation of potato planting density is an important way to ensure the high yield and quality in the field [16, 19]. Presently, traditional and ridges-single-row planting models are widely used across China and in the different parts of the world at seedlings rate of 3000-4000 per mu [22]. It is clear that the low density planting system can increase the field canopy ventilation, light transmission (Fig. 4), and drainage facilities [11-12, 23]. Winter season in Yunnan Province has low temperature and less rainfall, both conditions, reduce the occurrence and prevalence of late blight. Therefore, taking advantage of its winter climate and meteorological conditions and appropriately adopt high density planting approach at the rate of 5,558 seedlings per mu would effectively increase the yearly potato yields production (Tab. 7-8).

Mulching: The effect of different of soil covers on potato growth plays a big role in potato yield production [24, 28-29]. The soil cover thickness may explain the increase in soil moisture content (Fig. 5) which has greater effect on roots extension [13] which has positive impact on potato tubers development. Mulching with about $15 \mathrm{~cm}$ soil covering depth (Fig. 3B, C) has significantly stem and roots development with reduction of the green-headed potato rate and increasing of commercial yield products (Tab. 6) as reported that potato tubers value increases with soil cover thickness [18, 25-27] .

\section{Popularization, application and prospect of efficient winter potato cultivation model}

The planting model (single ridge- double row, secondary soil covering, and high-density planting) has been demonstrated and promoted in some areas of Yunnan Province (Fig. 6). Among them, the highest output in Jianshui County, Honghe Prefecture has reached to the average of 5.6tons/mu whereas in Shiping County and Shuangjiang County the yield exceeds 4 tons/mu. The average mu output in other pilot areas can exceed 3 tons, and the cumulative promotion area has exceeded 10,000 $\mathrm{mu}$ since 2013. At present, Yunnan Province winter potato yield production is ranked the first in the China, and planting area has reached 2.49 million mu in 2021. 


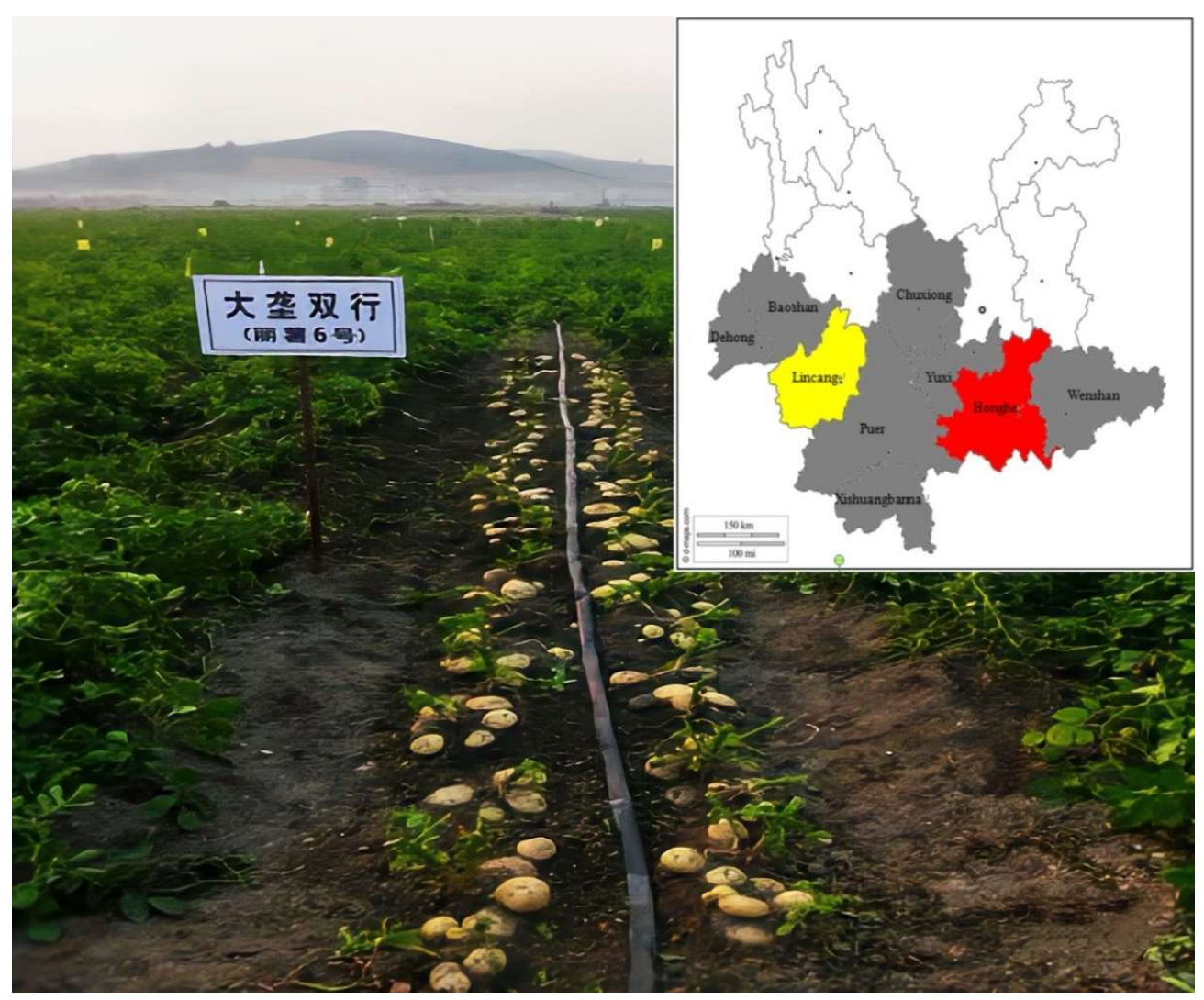

Figure 6. The planting model (single ridge- double row, secondary soil covering, and high-density planting) extension zones.

\section{Conclusion}

To maximize potato yield production, it is necessary to adopt the dominant cultivation model. Our study showed that ridge-double row, high density at the rate of 5558 seedlings per $\mathrm{mu}$, and twice soil covering about $10 \mathrm{~cm}$ depth can increase the potato productivity average from 1.2 of the current used cultivation model to 3 tons per mu. Therefore, the combination of this method with modern agriculture mechanization should be further popularized and applied in large scale planting in regions with climatic conditions similar winter season in Yunnan Province. This could effectively facilitate potato cultivation, and reduces the standard planting costs and increase potato production industry at the large scale to satisfy the world potato need which support United Nations SDGs (1, 2, and 12).

Author Contributions: “Conceptualization, Z.H.J. and Y.D.C.; methodology, Z.H.J.P.J, Z.B.J.; validation, Z.H.J. and Y.D.C.; formal analysis, P.J, Z.L.; investigation, X.S., Z.B.J; resources, Z.H.J. and Y.D.C.; data curation, N.E, P.J.; writing-original draft preparation, N.E, P.J., Z.B.J.; writing-review and editing, N.E, P.J..; visualization, N.E; supervision, Z.H.J. and Y.D.C. All authors have read and agreed to the published version of the manuscript."

Funding: "This research was funded by Yunnan Provincial Department of Science and Technology Major Science and Technology Special Program, grant number 202102AE090018" and "Key Research and Development Program of Hainan, grant number ZDYF2021XDN291".

Data Availability Statement: "Not applicable" here.

Acknowledgments:In this section, you can acknowledge any support given which is not covered by the author contribution or funding sections. This may include administrative and technical support, or donations in kind (e.g., materials used for experiments). 
Conflicts of Interest:"The authors declare no conflict of interest." "The funders had no role in the design of the study; in the collection, analyses, or interpretation of data; in the writing of the manuscript, or in the decision to publish the results".

\section{References:}

1. Statista.Potato production worldwide from 2002 to 2019 (in million metric tons). (Accessed from https://www.statista.com/statistics/382174/global-potato-production/) [02 Dec. 2021]

2. CIP (International Potato Center). Potato facts and figures. Accessed [02 Dec. 2021]

3. Atlas Big. World's Leading Potato Producing Countries. https://www.atlasbig.com/en-in/countries-by-potato-production) [02 Dec. 2021]

4. CIP (International Potato Center). Potential Opportunities for Potato Industry's Development in China Based on Selected Companies Final Report, 2018. (Accessed from https://potatocongress.org/) [02 Dec. 2021]

5. Zhong, L.; Yin, D.X.; Zhang, Y.C.; Zhu, H.Y.; Yang G.Y.; Rego, T.J.; Suhas, P. W. Efficient Management of Water Resources for Improving the Livelihoods through Integrated Watershed Management Approach. Water Resources for Improved Livelihoods in China, Xiaoxincun Watershed, 2003. (Accessed from https://core.ac.uk/download/pdf/211012761.pdf) [02 Dec. 2021]

6. Kempenaar, C.; Pronk, A.; Haverkort, A.J.; Kessel, G.J.; Michielsen, I.M.; Ruijter, F.J.; Vries, S.D.; Lyu, D.; Wan,S.M; Li, Y.L.; Fan, G.; Bai, J.; Min, F.; Guo, M.; Zhang, S.; Yang, S.; Liu Z.Y.; \&Gao, Y.F. "China Potato GAP 2013-2016/ Results of a public private partnership on innovation of potato production in China." 2017. https://library.wur.nl/WebQuery/wurpubs/520068

7. FAO (2009)Global agriculture towards 2050. How to feed the world 2050. (Accessed from https://www.fao.org/fileadmin/templates/wsfs/docs/Issues_papers/HLEF2050_Global_Agriculture.pdf) [19 Nov. 2021].

8. Zhou, P.; Tang, T.X; He, X.H.; Guo, H.C. Analysis of Climatic Conditions in Winter Potato Cultivation Area in Yunnan. J. of China Potatoes, 2018, 32(01), 6-12.

9. Zhang, W. A preliminary report on high-yielding cultivation techniques of potato in semiarid areas of Gansu. China Agricultural Research in the Arid Areas, 2014, 26 (1), 103-105.

10. Xue, J.W.; Ren, W.J.; Yan, C.R. Effect of plastic film mulching and ridge planting on yield and water use efficiency of potato in Loess Plateau. Chinese J. of Agrometeo.,2014, 35(1), 74-79.

11. Kroschel J., Mujica N., Okonya J., Alyokhin A. Insect Pests Affecting Potatoes in Tropical, Subtropical, and Temperate Regions. In: Campos H., Ortiz O. (eds) The Potato Crop 2020; pp 251-306.https://doi.org/10.1007/978-3-030-28683-5 8

12. Mehmet, EC.; Noyan, K.; SevgiCaliskan. Effects of plant density on the yield and yield components of true potato seed (TPS) hybrids in early and main crop potato production systems. [J]. Field Crops Research 2009; 114,2.

13. Zhang, J.; Wang, J.; Chen, J.; Song, H.; Li, S.; Zhao, Y.; Tao, J. \& Liu, J. Soil Moisture Determines Horizontal and Vertical Root Extension in the Perennial Grass Loliumperenne L. Growing in Karst Soil. Front. Plant Sci. 2019; 10, 629. https://doi.org/10.3389/fpls.2019.00629

14. Kouwenhoven, J.K. \& Van Ouwerkerk, C. Optimum row spacing for potatoes. Potato Res. 1978; $21,195-215$. https://doi.org/10.1007/BF02356375

15. Andrade, M.H.; Da Silva, A.L.; Pesantes, L.G.; Christensen, C. \&Zotarelli, L. Seed Piece Spacing for Early-Maturing Table-Stock Potato Grown under Subtropical Conditions. American J. of Potato Research 2019; $\underline{10.1007 / \mathrm{s} 12230-021-09838-\mathrm{z}}$

16. Mhango, J. K.; Hartley, W.; Harris, W. E.; Monaghan, J. M. Comparison of Potato (SolanumTuberosum L.) Tuber Size Distribution Fitting Methods and Evaluation of the Relationship between Soil Properties and Estimated Distribution Parameters. TheJ. of Agri. Sci. 2021, 1-15.

https://doi.org/10.1017/S0021859621000952

17. Djaman, K., Koudahe, K., Koubodana, H.D. et al. Tillage Practices in Potato (Solanumtuberosum L.) Production: A Review. Am. J. Potato Res. 2022;https://doi.org/10.1007/s12230-021-09860-1

18. Van der Waals, J.E.; Krüger, K.; Franke, A.C. et al. Climate Change and Potato Production in Contrasting South African Agro-Ecosystems 3. Effects on Relative Development Rates of Selected Pathogens and Pests. Potato Res. 2013; 56, 67-84.https://doi.org/10.1007/s11540-013-9231-3

19. Zerga, K.; Getu, B.N. \& Mohammed, K. Effects of Intra-Row Spacing on Vegetative Growth Performance of Potato (Solanumtuberosum L ) at Wolkite University, Ethiopia. Inter. J. Photochem. andPhotobio.2017; 1, 2, 44-48. 
20. Ma, Z.M.; Lian, C.Y.; Zhang, L.Q. The influence of ridge, ditch, irrigation and cultivation on soil hydrothermal effect and spring wheat yield. J. Irrigation and Drainage2012; 31, 1, 120-123. DOI:10.13522/j. cnki. ggps. 2012.01.030.

21. Han, X. Application of double-row mechanized planting technology for potato Dalong in Jishishan County, Gansu Province. Agri. Machi.2021;2, 80-81. DOI:10.16167/j. cnki. 1000-9868.2021.02.052.

22. Duan, H.M.; Lu, X.; Zhou, X.J.; Li, F.F; Wen, G.H.; Wang, Y.P.; Cheng, L.X.; Zhang, F. The influence of potato leaf type and planting density on yield composition. J. Crops 2021; 1, 160-167. DOI:10.16035/j. issn. 1001-7283.2021.01.022.

23. Xu, G.C.; Li, H.W.; Luo, W.B; Ji, R.C.; Lin, Z.M.; Li, G.L.; Xu, Y.Q.; Tang, H. The influence of density, nitrogen application and its interaction on the yield of winter potatoes and the agronomic utilization rate of nitrogen fertilizer. Fujian Agri. J.2020; 35, 4, 406-413. DOI:10.19303/j. issn. 1008-0384.2020.04.007.

24. Chen, W.S.; Li, F.; Li, Y.P.; Wang, B.; Xue, Z.Z. Comparative study on the cultivation of bud ginger with different sowing quantities and different covering thicknesses. J. Fujian Radio and Telev. Univrsity 2018; 5, 43-47.

25. Ma, D.Y. Research on potato planting density, ridge and ditch depth and soil covering thickness, high-yield cultivation techniques. Friends of Farmers Getting Rich2019; 8, 155.

26. Meng, Y. Research on potato planting density, ridge and ditch depth and soil covering thickness, high-yield cultivation techniques. China Agri. Info.2017; 4, 70-72.

27. Chen Jiaji, GaoJianhua, Yan Lei, Yang Guocai, Chen Xiaoyan. The influence of different planting methods on reducing the proportion of green heads of potato tubers. Potato industry and Healthy consumption; Helongjia Science and Technology Publishing house, China 2019; pp285-288.

28. Nowroz, F.; Roy, T.; Haque, M.; Ferdous, J.; Noor, R.; Mondal, G. Yield and Grading of Potato (Solanumtuberosum L.) as Influenced by Different Mulch Materials. Agrotech. Industrial Crops2021; 1, 1, 1-10. doi: 10.22126/etic.2021.6209.1001

29. Hou, X.Q.; Li, R. Potato Tuber Yields in Semi-Arid Environments are Increased by Tillage and Mulching Practices. J. Agro.2018; 110, 6, 2641-2651. https://doi.org/10.2134/agronj2017.10.0606 